\title{
Hybrid Power Generation as an Environmental Friendly Energy Supply Solution for Remote Area in Indonesia
}

\author{
Burhanuddin Halimi
}

\begin{abstract}
This paper focuses on the optimal solution to provide a more environmental friendly electrical power supply for remote areas which usually have many problems regarding electricity supply. Due to their remote location, it is very impractical to deliver the electrical energy from power generation plants by using the conventional method. To solve this problem, generator sets are commonly utilized for providing electrical power for these kind of areas. But their fuel storage and transportation issues are not quite easy to be dealt with. Moreover, considering the environmental impacts, the use of fossil fuels should be minimized.

The proposed system adopts a stand-alone hybrid photovoltaic, wind turbine and fuel cell power system without battery storage support. The best combination of these three resources are computationally analyzed to get the optimal result. To obtain the optimal result, the proposed system is analyzed using HOMER software. By adopting the baseline load average of $225 \mathrm{~kW}$ or $5,397 \mathrm{kWh} / \mathrm{d}$ with peak load of $290 \mathrm{~kW}$, it was obtained that the optimal system is PV array of 7,000 kW, $6 \mathrm{x}$ $@ 250 \mathrm{~kW}$ wind turbines, fuel cell of $350 \mathrm{~kW}$ which is supported by $2,000 \mathrm{~kW}$ electrolyzer.
\end{abstract}

Index Terms-Fuel cell, hybrid system, photovoltaic, wind turbine.

\section{INTRODUCTION}

As one of the top ten largest archipelago countries in the world, Indonesia has more than seven thousands islands. Some of them are located in remote areas and associated with a lack of electricity supply condition. Then, due to their geographical location, it is impractical to utilize the conventional electrical power delivery method with high transmission lines. Currently, generator sets are generally used to provide electricity for those kind of areas in Indonesia. Considering the fuel transportation and environmental issues, the use of renewable energy resources in energy production is more assigned a priority to be adopted as the solution for providing a more environmental friendly and more sustainable electrical power supply.

To obtain the optimal condition of the use of renewable energy resources, a hybrid system is more suitable to increase the system reliability and security [1]. But due to their natural characteristics, renewable energy sources are quietly difficult to be targeted for providing a constant power. Hence, it is commonly to obtain more continuous electrical power output, they are supported by energy storage devices such as batteries [2].

Manuscript received August 24, 2016; revised October 28, 2016.

B. Halimi is with School of Electrical Engineering and Informatics, Institut Teknologi Bandung, J1. Ganesa 10 Bandung, Indonesia (e-mail: burhan@konversi.ee.itb.ac.id).
In this paper, it is proposed a hybrid system using photovoltaic (PV), fuel cell (FC) and wind turbine. In this system, the fuel cell is fueled by hydrogen which produced by an electrolyzer powered by the electrical energy from the renewable energy source. The proposed system is analyzed by using HOMER software to ensure that the final result is the most optimal one.

\section{POTENTIAL RENEWABLE ENERGy RESOURCES IN INDONESIA}

As one of tropical countries in the world, Indonesia has a lot of renewable energy resources which can be utilized as an alternative solution of providing electrical power, such asolar energy, wind energy, ocean energy, biomass energy etc. This paper will be focused on solar energy, fuel cell, and wind energy as an alternative solution for more environmental friendly electric power supply.

\section{A. Solar Energy}

As the one of the biggest archipelago countries that stretched along the equator, the potency of solar irradiation over Indonesia is ranging between $4.6 \mathrm{kWh} / \mathrm{m}^{2}$ and 7.2 $\mathrm{kWh} / \mathrm{m}^{2}$ [3]. The eastern parts of Indonesia have the more potential solar energy compared to the western ones during whole year, especially in Bali, Lombok, Kupang, Manado, Palu, Makasar, Gorontalo, Ambon, and Ternate.

The more common way to harvest the solar energy is by utilizing photovoltaic (PV) module systems. In a PV module, the solar energy is converted via photovoltaic effect which directly converts the incident light into electricity by a pn (or p-i-n) semiconductor junction device [4]. A grid-connected PV system is illustrated in Fig. 1.

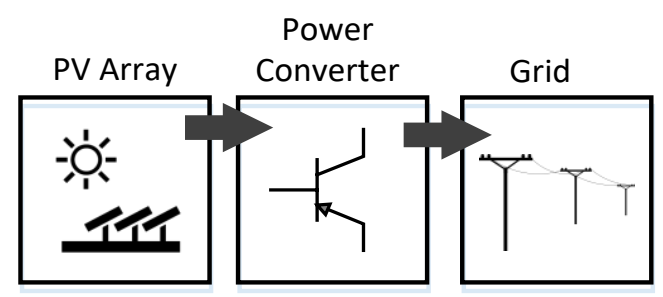

Fig. 1. A grid-connected PV system [5].

\section{B. Wind Energy}

Nowadays, wind energy is still one of the most promising renewable energy sources [6]. Indonesia has potency of 3-6 $\mathrm{m} / \mathrm{s}$ [7]. In term of technology, wind energy conversion technology has been rapidly developed since 1990s.

Generally, the main components of a wind energy conversion system are illustrated in Fig. 2. [8]. The system 
consists of a turbine rotor, a gearbox, a generator, and a power electronics converter which does the job to make sure that the electrical power output is fit to the grid requirements.

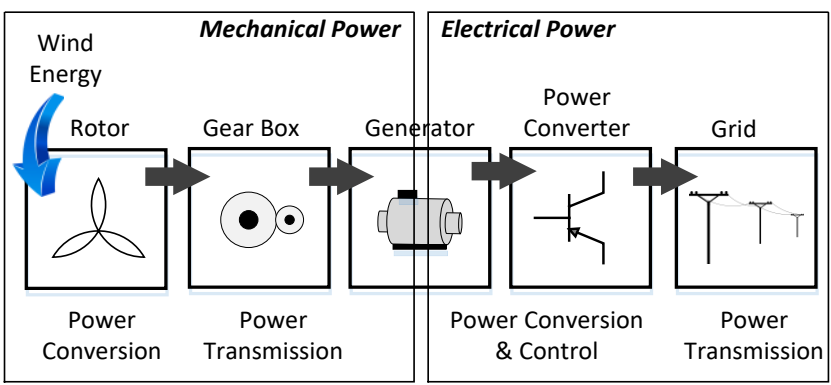

Fig. 2. Wind turbine system.

\section{Fuel Cell}

Similar as batteries, fuel cells are electrochemical devices that have a capability to convert their internal chemical energy directly to electrical energy with high efficiency. Due to this capability, fuel cell systems were adopted as backup power solutions in telecommunications applications [9].

The basic working principle of a fuel cell is illustrated in Fig. 3. By utilizing hydrogen as the working fuel, the following reaction will be occurred

$$
\begin{array}{ll}
\text { Anode } & : \mathrm{H}_{2} \rightarrow 2 \mathrm{H}^{+}+2 \mathrm{e}^{-} \\
\text {Cathode } & : 1 / 2 \mathrm{O}_{2}+2 \mathrm{H}^{+}+2 \mathrm{e}^{-} \rightarrow \mathrm{H}_{2} \mathrm{O} \\
\text { Total reaction } & : \mathrm{H}_{2}+1 / 2 \mathrm{O}_{2} \rightarrow \mathrm{H}_{2} \mathrm{O} \quad \text { (eksoterm) }
\end{array}
$$

Thus, the total reaction of hydrogen and oxygen in a fuel cell does not only generate direct current $(\mathrm{dc})$ electrical power as the main product, but it also produces water and heat as the reaction's byproducts. Both of these byproducts are not only environmental friendly products, they can be utilized to enhance the system's total efficiency as same as in a combined cycle power plant system.

Moreover, due the electrical power output is in dc form, a power conditioning system should be added in the fuel cell system. Similar with the PV system, this power conditioning system do converting the fuel cell's dc power output to ac power form and making sure that the ac electrical power output is fit to the load or grid requirements.

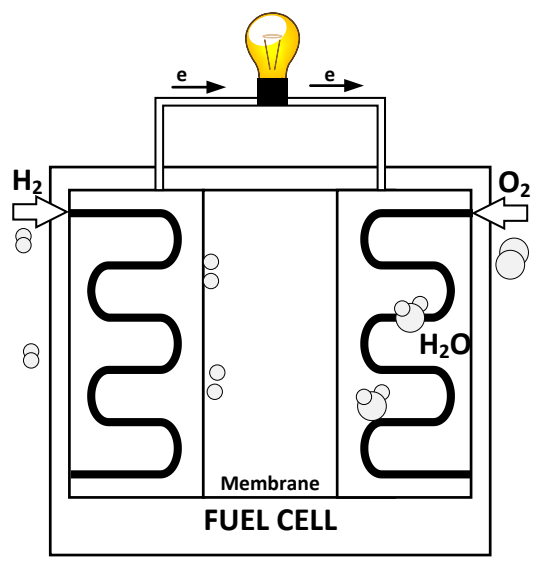

Fig. 3. Fuel cell working principle.

Compared to the other renewable power sources, fuel cell has some excellences such as high efficiency, not need recharging, possibility to run continuously, no moving parts, no noise, etc. The main constrain of the fuel cell is same as the other renewable energy resources i.e. its high cost in investment phase.

\section{HYBRID SYSTEM PROPOSED SOLUTION}

Indonesian electrical power systems network can be generally described as illustrated in Fig 4. As shown in this figure, Indonesia adopts $20 \mathrm{kV}$ system as the working medium voltage for the distribution level. Especially for the residential customers, the $20 \mathrm{kV}$ voltage will be step-downed by the distribution transformer to voltage value of $220 / 380 \mathrm{~V}$. A typical $400 \mathrm{kVA}$ distribution transformer, as shown in Fig. 5, can supply more than 400 residential customers.

In this paper, a hybrid system based on renewable energy resources is proposed as illustrated in Fig. 6. The proposed system adopts PV, wind turbine and fuel cell as the energy resources.

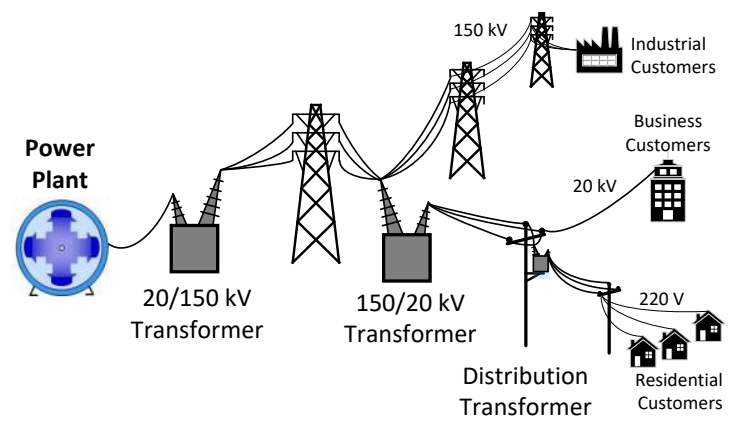

Fig. 4. Typical electrical power system network in Indonesia [10].

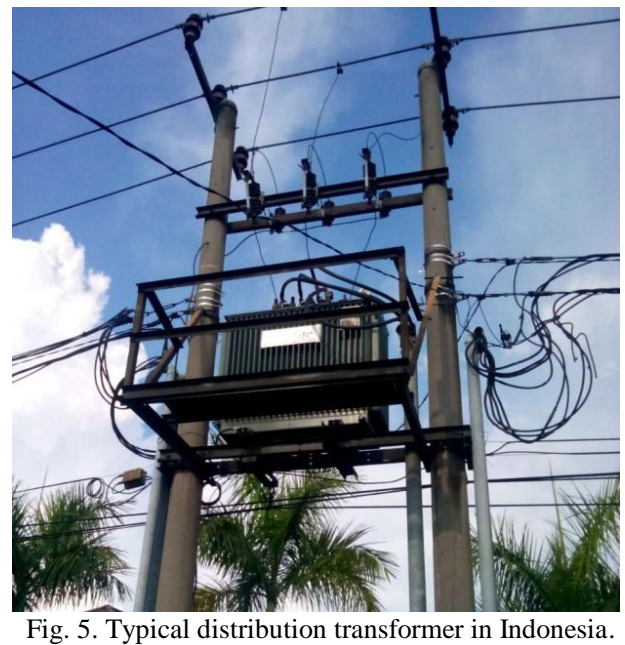

\section{COMPUTATIONAL ANALYSIS}

To check the proposed design, the HOMER software is used. HOMER is a micropower optimization model tool which has a capability to simplify the task of evaluating designs of both off-grid and grid-connected power systems for a various applications [11]. In HOMER, the proposed system can be modeled as described in Fig. 7. In this study, the focused variables are PV array size, FC size, DC-AC converter size, electrolyzer \& hydrogen storage tank sizes, and wind turbine size. Then, HOMER input data are provided by Tables I and II. 


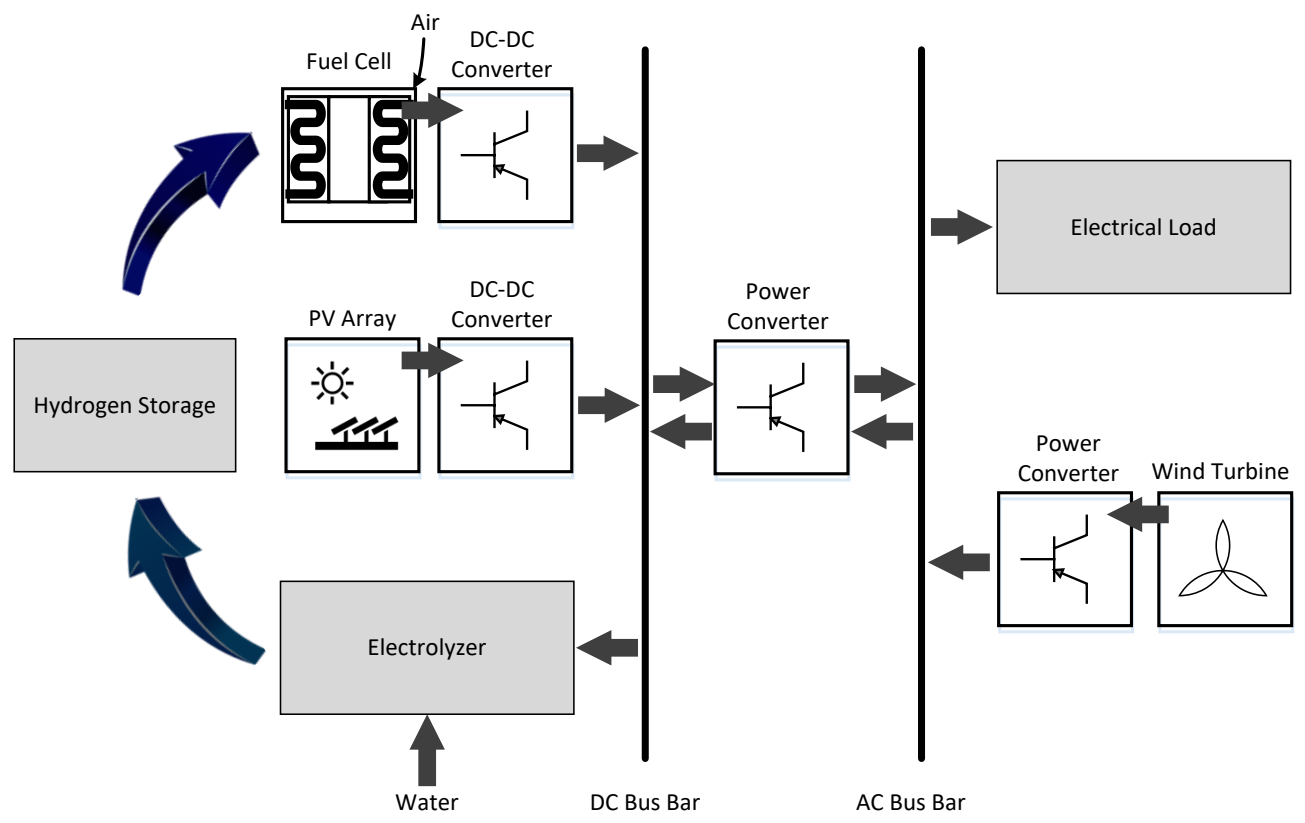

Fig. 6. Schematic of the proposed hybrid system.

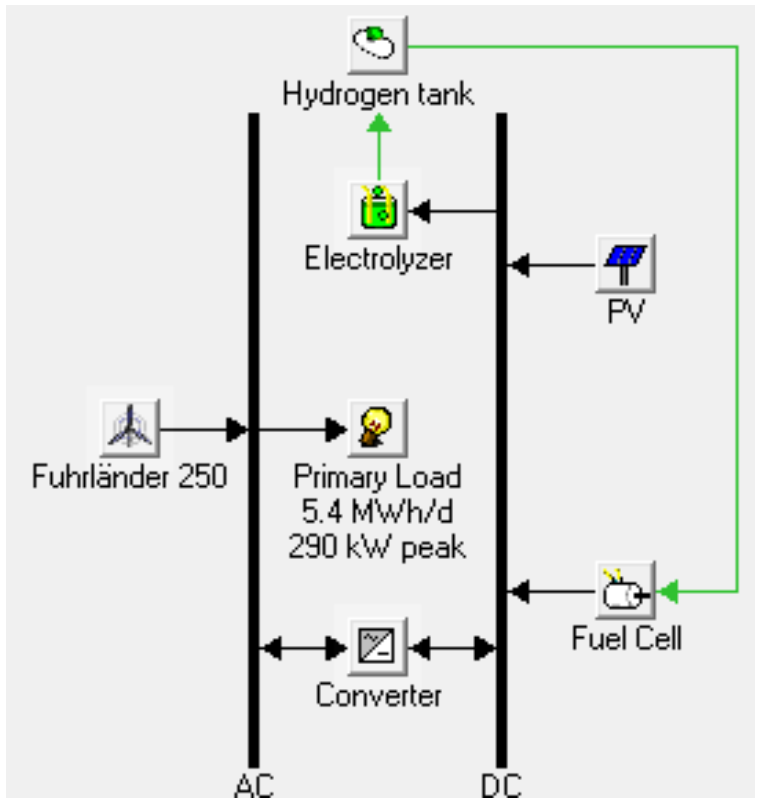

Fig. 7. The proposed system model in HOMER.

\section{A. Case Study}

Residential customers in a remote area where is located at -6. Latitude and 106 longitude is adopted as the customers of the distribution substation. Total number of houses which has to be supplied is 461 houses. The electrical load profile is illustrated in Fig. 8, where the baseline load average and the peak load are $225 \mathrm{~kW}$ or $5,397 \mathrm{kWh} / \mathrm{d}$ and $290 \mathrm{~kW}$, respectively. The total load has been scaled to $5,400 \mathrm{kWh} / \mathrm{d}$.

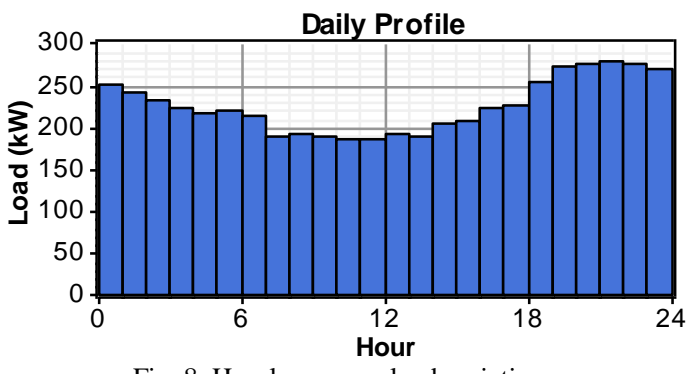

Fig. 8. Hourly average load variation.
TABLE I: COST INPUT DATA

\begin{tabular}{lccc}
\hline \hline Components & $\begin{array}{c}\text { Capital } \\
\text { Cost } \\
{[\$ / \mathrm{kW}]}\end{array}$ & $\begin{array}{c}\text { Replacement } \\
\text { Cost }\end{array}$ & O\&M Cost \\
\hline PV & 6,000 & 5,000 & $0 \$ / \mathrm{yr}$ \\
Fuel Cell & 3,000 & 2,700 & $0.020 \$ / \mathrm{hr}$ \\
Converter & 950 & 850 & $10 \$ / \mathrm{yr}$ \\
Electrolyzer & 2,000 & 1,800 & $30 \$ / \mathrm{yr}$ \\
Hydrogen Tank & 1,300 & 1,200 & $10 \$ / \mathrm{yr}$ \\
Wind Turbine & $1,500 *$ & $1,300 *$ & $25 \$ / \mathrm{yr}$ \\
\hline \hline
\end{tabular}

TABLE II: COMPONENTS SIZING

\begin{tabular}{lccc}
\hline \hline Components & Size $[\mathrm{kW}]$ & Life $[\mathrm{yr}]$ & Other \\
\hline PV & $0 ; 7,000 ;$ & 25 & $\begin{array}{c}\text { Derating f.: } 70 \% \\
\text { Slope: } 83^{\circ}\end{array}$ \\
& 7,$500 ; 8,000$ & 25 & Min. load: $1 \%$ \\
Fuel Cell & $0 ; 350 ; 400 ;$ & $40,000^{1}$ & Inverter Eff.: \\
& 450 & & $95 \%$ \\
Converter & $0 ; 350 ; 400 ;$ & 10 & Eff. : $80 \%$ \\
& 500 & & - \\
Electrolyzer & $0 ; 2,000 ;$ & 25 & Hub Height: \\
Hydrogen Tank & 2,$500 ; 3,000$ & & $10 \mathrm{~m}$ \\
Wind Turbine & $0 ; 7,000 ;$ & 25 & 15 \\
\hline \hline
\end{tabular}

${ }^{1}$ Operating hours

${ }^{2}$ Quantity [unit]

The solar and wind data of the case study location were obtained from NASA Surface Meteorology and Solar Energy [12]. Fig. 9 and Fig. 10 depict the solar radiation and wind speed profile over a one-year period. The annual average solar radiation and wind speed for this area are about 4.815 $\mathrm{kWh} / \mathrm{m}^{2} /$ day and $3.814 \mathrm{~m} / \mathrm{s}$, respectively.

\section{B. Computational Results}

Based on HOMER analysis, the optimization of proposed hybrid system results are summarized by Table III. This table shows that the optimal energy source combination consists of PV array with total capacity of 7,000 kW, 6 units of $250 \mathrm{~kW}$ wind turbine, fuel cell of $350 \mathrm{~kW}$ which should be supported 
by 2,000 kW electrolyzer. Also, to convert the DC power of $\mathrm{PV}$ array and fuel cell sources to AC power, a set of power electronics converter with total capacity of $350 \mathrm{~kW}$ must be utilized to do this conversion task. This system will initially cost $\$ 138,395,472$ with operating cost of $\$ 902,833 /$ year. Then, considering the current technology development, if the fuel cell capital can be optimistically pressed down to $25 \%$, the initial cost of this system will be significantly reduced to be $\$ 66,354,972$ with operating cost of $\$ 839,576 /$ year as illustrated in Table IV.
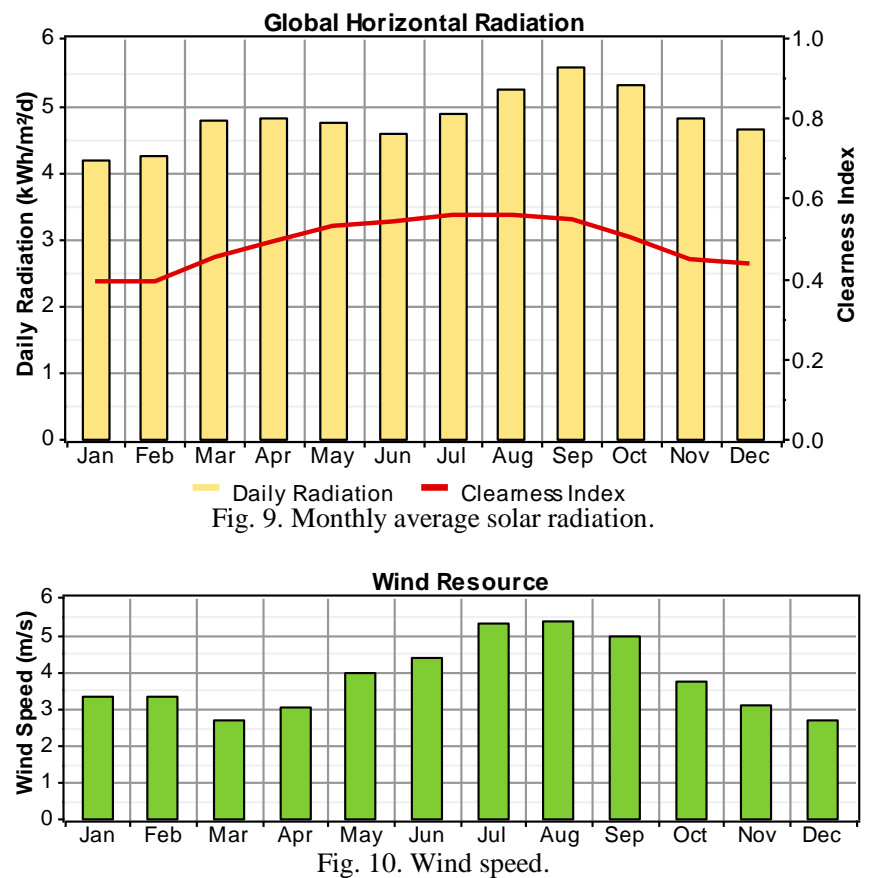

Moreover, Table V and VI show the detail annual electric energy production and consumption, respectively. In Table V, it can be concluded that more than seventy five percent of the electrical energy is produced by PV array. The wind turbines are annually contribute only four percent to the system in term of power production. In the other hands, it must be noted that most of electrical energy is consumed by the electrolyzer load where the AC primary load consumes only $36 \%$ of total power Also, considering the environmental impacts, this proposed hybrid systems can reduce the $\mathrm{CO}_{2}$ emission by $685 \mathrm{~kg} / \mathrm{yr}$. as described in Table VII. This value is more excellently compared to the typical conventional bituminous coal-fired power plant which emits 2.07 pounds of $\mathrm{CO}_{2} / \mathrm{kWh}$ [13].

\begin{tabular}{lc}
\multicolumn{2}{c}{ TABLE III: OPTIMIZATION RESULTS } \\
\hline \hline PV [kW] & 7,000 \\
Fuel Cell [kW] & 350 \\
Converter [kW] & 350 \\
Electrolyzer [kW] & 2,000 \\
Hydrogen Tank [kg] & 70,000 \\
Wind Turbine @250 kW [unit] & 6 \\
Initial Capital Cost [\$] & $138,395,472$ \\
Operating Cost [\$/yr] & 902,833 \\
Total NPC & $149,936,704$ \\
COE [\$kWh] & 5.951 \\
\hline *\$unit
\end{tabular}

In term of power and hydrogen productions, Fig. 11 and 12 illustrate the monthly average electric production of $\mathrm{PV}$, wind turbine and FC and hydrogen production of electrolyzer, respectively. It is clearly shown that PV array dominates in term of electric power production for all months.

TABLE IV: OPTIMIZATION RESULTS [FC CAPITAL: 25\%]

\begin{tabular}{lc}
\multicolumn{2}{c}{ TABLE IV: OPTIMIZATION RESULTS [FC CAPITAL: $25 \%$ ] } \\
\hline \hline Initial Capital Cost [\$] & $66,354,972$ \\
Operating Cost [\$/yr] & 839,576 \\
Total NPC & $77,087,568$ \\
COE $[\$ \mathrm{kWh}]$ & 3.060 \\
\hline \hline
\end{tabular}

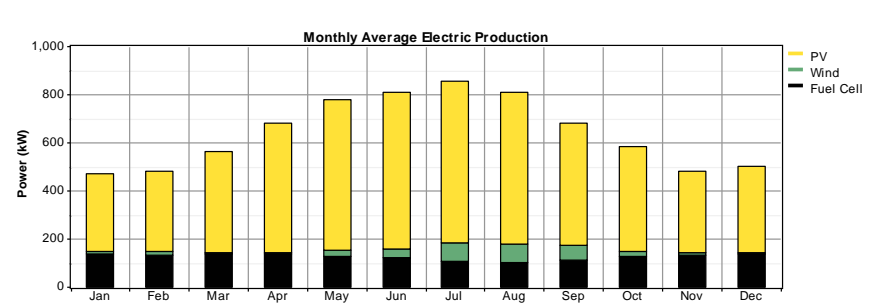

Fig. 11. Average electric production.

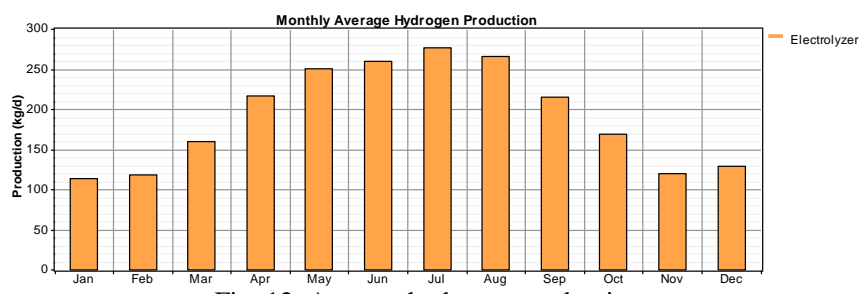

Fig. 12. Average hydrogen production.

TABLE V: ANNUAL ELECTRICAL PRODUCTION

\begin{tabular}{lcc}
\hline \hline Production & kWh/yr. & $\%$ \\
\hline PV Array & $4,263,223$ & 76 \\
Wind Turbines & 251,035 & 4 \\
Fuel Cell & $1,117,154$ & 20 \\
Total & $5,631,412$ & 100 \\
\hline \hline \multicolumn{2}{c}{ TABLE VI: ANNUAL ELECTRICAL CONSUMPTION } \\
\multicolumn{2}{c}{ kWh/yr. } \\
\hline \hline Consumption & $1,971,002$ & $\%$ \\
\hline AC Primary Load & $3,453,473$ & 36 \\
Electrolyzer Load & $5,424,475$ & 64 \\
Total &
\end{tabular}

TABLE VII: SYSTEM EMISSIONS

\begin{tabular}{lc}
\hline \hline Components & Emissions $[\mathrm{kg} / \mathrm{yr}]$. \\
\hline Carbon Dioxide & -685 \\
Carbon Monoxide & 436 \\
Unburned Hydrocarbons & 48.3 \\
Particulate Matter & 32.8 \\
Sulfur Dioxide & 0 \\
Nitrogen Oxides & 3,888 \\
\hline \hline
\end{tabular}

\section{CONCLUSION}

An environmental friendly electrical power supply for remote areas in Indonesia was proposed in this paper. The proposed system adopts a stand-alone hybrid photovoltaic, wind turbine and fuel cell power system without battery storage support. The optimal solution was obtained by using HOMER software. By adopting the baseline load average of $225 \mathrm{~kW}$ or $5,397 \mathrm{kWh} / \mathrm{d}$ with peak load of $290 \mathrm{~kW}$ as the case study, it was obtained that the optimal system is PV array of $7,000 \mathrm{~kW}, 6 \mathrm{x} @ 250 \mathrm{~kW}$ wind turbines, fuel cell of $350 \mathrm{~kW}$ which is supported by $2,000 \mathrm{~kW}$ electrolyzer. The computational results showed that the proposed hybrid system can produce totally $5,631,412 \mathrm{kWh} / \mathrm{yr}$. for supplying total demands of $5,424,475 \mathrm{kWh} / \mathrm{yr}$. Also, considering the 
environmental impacts, the proposed hybrid systems can reduce the $\mathrm{CO}_{2}$ emission by $685 \mathrm{~kg} / \mathrm{yr}$.

\section{REFERENCES}

[1] O. H. Mohammed, Y. Amirat, M. E. H. Benbouzid, and T. Tang, "Hybrid generation systems planning expansion forecast: A critical state of the art review," in Proc. the 2013 IEEE IECON, Vienna (Austria), pp. 1666-1671, November 2013.

[2] E. Kabalci, "Design and analysis of a hybrid renewable energy plant with solar and wind power," Energy Conversion and Management, vol. 72, pp. 51-59, August 2013.

[3] M. Rumbayan, A. Abudureyimu, and K. Nagasaka, "Mapping of solar energy potential in Indonesia using artificial neural network and geographical information system," Renewable and Sustainable Energy Reviews, vol. 16, pp. 1437-1449, 2012

[4] R. W. Miles, K. M. Hynes, and I. Forbes, "Photovoltaic solar cells: An overview of state-of-the-art cell development," Progress in Crystal Growth and Characterization of Materials, vol. 51, 2005, pp. 1-42.

[5] E. Koutroulis and F. Blaabjerg, "Design optimization of grid-connected PV inverters," presented at Twenty-Sixth Annual IEEE Applied Power Electronics Conference and Exposition (APEC), 2011

[6] F. Blaabjerg and K. Ma, "Future on power electronics for wind turbine systems," IEEE Journal of Emerging and Selected Topics in Power Electronics, vol. 1, no. 3, September 2013

[7] Dewan Energi Nasional Republik Indonesia, Outlook Energi Indonesia, 2014.
[8] Z. Chen, J. M. Guerrero, and F. Blaabjerg, "A review of the state of the art of power electronics for wind turbines," IEEE Transactions on Power Electronics, vol. 24, no. 8, August 2009.

[9] A. Tomasi and R. Marin, "Fuel cell backup solution in BTS station: First project in Italy," presented at IEEE $29^{\text {th }}$ International Telecommunications Energy Conference (INTELEC), 2007.

[10] Lampung. [Online].

Available: http://www.pln.co.id/lampung/?p=3551

[11] Getting Started Guide for HOMER Version 2.1, National Renewable Energy Laboratory (NREL), 2005.

[12] Larc.nasa. [Online]. Available: https://eosweb.larc.nasa.gov/

[13] Eia. [Online]. Available: https://www.eia.gov/

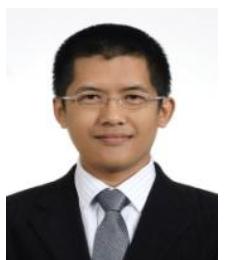

Burhanuddin Halimi is with School of Electrical Engineering and Informatics, Institut Teknonologi Bandung. He received the B.S. degree and M.S. degree in electrical engineering from Institut Teknologi Bandung, Indonesia in 2000 and 2002, respectively; his Ph.D. degree in energy systems Engineering from Seoul National University, Republic of Korea in 2013. Since 2014 he is working as one of faculty members in School of Electrical Engineering and Informatics, Institut Teknonologi Bandung. His current research interests include electric power generation, energy conversion, renewable energy application, electric propulsion and thermal energy management. 